\title{
Wpływ idei Komisji Edukacii Narodowej na organizacje szkolnictwa w Rosji w pierwszej połowie XIX wieku
}

\author{
The Influence of the Ideas Propagated by the National \\ Education Commission on the Educational System in \\ Russia in the First Half of the 19th Century
}

\begin{abstract}
ABSTRAKT
Po likwidacji Komisji Edukacji Narodowej i utracie niepodległości, już na poczqtku XIX wieku w warunkach niewoli rosyjskiej myśli i koncepcje KEN z powodzeniem wykorzystywali Adam Jerzy Czartoryski, Hieronim Stroynowski, Hugo Kołłąaj, Tadeusz Czacki i wielu innych. Z jednej strony brali oni udział w reformowaniu szkolnictwa rosyjskiego, w dużej mierze opierajq̨c się na założeniach i ideach KEN, z drugiej starali się w jego strukturze zachować, a nawet rozwinqć szkoły polskie. Dzięki temu idee KEN ukształtowane w obliczu upadku Państwa Polskiego mogły uświadomić Rosjanom, że podstawy nowoczesnego systemu oświaty dali im przedstawiciele narodu przez nich podbitego. Specyfikq tego systemu był podział kraju na okręgi szkolne, które zostały utworzone przy uniwersytetach. Jednym z owych okręgów był Wileński Okręg Szkolny (Naukowy), w kłórym obowiqzywał polski ięzyk nauczania. Tym samym, najważniejszym ośrodkiem naukowym ziem litewsko-ruskich stał się Cesarski Uniwersytet Wileński, a pod zwierzchnictwo uczelni wileńskiej przeszły wszystkie placówki oświatowe w zaborze
\end{abstract}

Articles and dissertations
SLOWA KLUCZOWE Komisja Edukacii Narodowej, pierwsza połowa XIX w., szkolnictwo w Imperium Rosyjskim, Wileński Okręg Szkolny, Adam Jerzy Czartoryski

KEY WORDS

National Education Commission, first half of the 19th century, education in the Russian Empire, The Vilnius School District, Adam Jerzy Czartoryski

SPI Vol. 19, 2016/3

ISSN 2450-5358

e-ISSN 2450-5366 DOI: 10.12775/SPI.2016.3.003 Artykuły i rozprawy 
rosyjskim, w tym częściowo również te, które wcześniej podlegały Szkole Głównej Koronnej w Krakowie. Pod opiekq odnowionego uniwersytetu znalazły się więc zarówno dawne szkoły KEN, które przetrwały zawieruchę rozbiorów, jak i nowe, powstałe w okresie funkcjonowania Wileńskiego Okręgu Naukowego. Taki stan rzeczy trwał niemal trzydzieści lat, praktycznie do wybuchu powstania listopadowego. Wówczas zamknięto większość szkół polskich, a Wileński Okręg Narodowy został zlikwidowany. Upadek powstania stanowił więc zarówno symboliczny, jak i faktyczny kres funkcjonowania idei KEN na terenie Imperium Rosyjskiego. Struktura szkolnictwa oparta na dawnej koncepcji KEN jednak pozostała.

\section{ABSTRACT}

When the National Education Commision ceased functioning and Poland had lost its independence as early as in the beginning of the 19 h century under Russian rule, ideas and concepts that had been propagated by the Commision were successfully implemented by Adam Jerzy Czartoryski, Hieronim Stroynowski, Hugo Kołłqqai, Tadeusz Czacki and many others. On the one hand, they contributed to the reforms of the Russian educational system, where such reforms were largely based on the premises and ideas of the Commission; on the other hand, said thinkers attempted to preserve, and even develop Polish schools within this system. Consequently, the ideas of the National Education Commision developed on the eve of the fall of Poland made the Russians realize that the representatives of the conquered nation had provided Russia with the basis of a modern educational system. The uniqueness of this system was the division of the country into school districts that were created at universities. One of them was the Vilnius School District where Polish was the language of schooling. Thus, the Imperial University of Vilnius became the most important academic centre in the Lithuanian-Russian state. The University of Vilnius assumed authority over all educational institutions in the Russian Partition, including some of those that had been earlier subordinated to the Main Crown School in Kraków. The renamed University of Vilnius thus supervised both schools previously established by the National Education Commission that had survived the turmoils of partitions and new ones created when the Vilnius School District began to function. Such an organizational structure lasted for nearly thirty years until the outbreak of the November Uprising. Then, most Polish schools were closed down and the Vilnius School District was dissolved. The fall of the Uprising marked both a symbolic and actual end to the ideas of the National Education Commission for the Russian Empire. However, the school organizational structure based on the old conception of the Commission remained intact. 


\section{Wstęp}

Komisja Edukacji Narodowej, a właściwie Komisja nad Edukacja Mtodzi Szlacheckiej Dozór Mającej, została powołana na mocy uchwały Sejmu z 14 października 1773 roku. Funkcjonowała bez większych przeszkód aż do roku 1793, a istniała faktycznie do połowy kwietnia 1794 roku. Kres Komisji zbiegł się z upadkiem powstania kościuszkowskiego, a wkrótce także z trzecim rozbiorem i likwidacją Państwa Polskiego.

\section{Dzieło Komisji Edukacii Narodowej}

Komisja stanowiła jedno z naszych największych osiągnięć czasów Oświecenia. Pod względem poziomu i organizacji szkolnictwa Polska znalazła się w czołówce krajów europejskich, jako pierwsza wcielała w życie nowe idee pedagogiczne ${ }^{1}$. Przede wszystkim, Komisja Edukacji Narodowej stworzyła podwaliny pod nowoczesny system szkolny: sprawną administrację, unowocześnione programy nauczania i podręczniki, świecka kadrę nauczającą. Wytyczyła jasno cele wychowania, wprowadziła metody kształcenia oparte na doświadczeniu i racjonalnym ujmowaniu zjawisk. Szeroka działalność KEN „przeobraziła nie tylko szkolnictwo, ale wpłynęła na całokształt kultury polskiej i pozostawiła trwalszy dorobek niż jakiekolwiek wcześniejsze czy też późniejsze przemiany szkolne i koncepcje pedagogiczne"2.

Trzeci rozbiór Polski oznaczał nie tylko likwidację państwa, ale był też definitywnym końcem działalności KEN oraz szkolnictwa polskiego opartego na jej założeniach. Jednak myśli i koncepcje Komisji, w tym swoisty kodeks szkolny, czyli Ustarwy z 1783 i 1790 roku, przeżyły samą instytucję i nie poszły w zapomnienie. Przede wszystkim Rosjanie na początku XIX wieku z powodzeniem wykorzystywali je przy tworzeniu nowoczesnego systemu szkolnictwa na terenie swojego Imperium ${ }^{3}$ - w dużej mierze czynili to za pośrednictwem

1 K. Mrozowska, Tradycje Komisji Edukacji Narodowej w szkolnictwie polskim w XIX wieku, „Przegląd Historyczno-Oświatowy” 1971, s. 403.

2 Tamże.

3 K. Bartnicka, Ustawy dla Stanu Akademickiego i na szkoty w krajach Rzeczypospolitej przepisane. Polski kodeks szkolny z XVIII wieku, opublikowany w 1783 r. przez Komisje Edukacji Narodowej. (Wprowadzenie do nowego wydania), 
Polaków. Wielu z nich po upadku państwa polskiego znalazło się na dworze petersburskim, a służąc carowi i pomagając m.in.w organizacji szkolnictwa, wykorzystywali myśl i koncepcje KEN. Szczególnie było to widoczne na terenie zagarniętym przez Rosję w kolejnych rozbiorach.

Należy w tym miejscu przypomnieć, że w okresie funkcjonowania KEN na terenie województw wschodnich szkoły niższego szczebla podlegały zarówno Akademii Wileńskiej, jako Szkole Głównej Wielkiego Księstwa Litewskiego, jak i Akademii Krakowskiej (Szkole Głównej Koronnej) ${ }^{4}$. W wyniku trzech rozbiorów i wymazania Polski z mapy Europy, ziemie polskie przeszły pod panowanie trzech zaborców, a szkoły znalazły się $\mathrm{w}$ trzech odmiennych systemach oświaty. Wilno dostało się pod panowanie rosyjskie, Kraków natomiast pod władanie Austrii.

Problematyka dotycząca wpływu idei KEN na szkolnictwo rosyjskie $\mathrm{w}$ pierwszej połowie XIX wieku ${ }^{5}, \mathrm{w}$ tym na organizację i funkcjonowanie szkół na terenie zaboru rosyjskiego, nie jest tematem nowym. Zagadnienie to ciągle jednak budzi zarówno emocje, jak refleksje, choćby w kontekście roli Polaków w tworzeniu nowoczesnego systemu oświaty na terenie Imperium Rosyjskiego. Dzięki temu idee KEN, ukształtowane w obliczu upadku Państwa Polskiego, mogły uświadomić Rosjanom, że podstawy w tym zakresie dali im przedstawiciele narodu przez nich podbitego.

\section{Szkolnicłwo polskie w zaborze rosyjskim po III rozbiorze}

W zaborze rosyjskim początkowo założenia programowe władz carskich wobec zagarniętych ziem i ludności były jednoznaczne: „rozszerzenie prawosławia i rusyfikacja”. W konsekwencji, w Rosji w pierwszych latach po likwidacji Rzeczypospolitej, polska oświata

w: Ustawy Kommissyi Edukacji Narodowej dla Stanu Akademickiego i na szkoty w krajach Rzeczypospolitej przepisane. Wydane z oryginału ze zbiorów Biblioteki Uniwersyteckiej w Warszawie. Pierwsze pełne wydanie z tabelami i wzorami od 1783 roku, red. naukowa K. Bartnicka, Warszawa 2015, s. 52.

4 R. Wroczyński, Dzieje ośzwiaty polskiej do roku 1795, Warszawa 1987, s. 264.

5 Faktycznie w pierwszych trzech dekadach XIX w.

6 E. Danowska, Tadeusz Czacki 1765-1813. Na pograniczu epok i ziem, Kraków 2006, s. 240. 
znalazła się w najgorszej sytuacji. Polityka Katarzyny II i Pawła I była nieprzychylna kontynuowaniu dzieła KEN, a szkoły, które w wyniku rozbiorów znalazły się na terenie imperium, usiłowano przekształcić „na obraz i podobieństwo szkół rosyjskich””.

Jednakże po objęciu władzy przez Aleksandra I na ziemiach zajętych przez Rosję doszło do zasadniczych zmian w nastawieniu do Polaków. W istotny sposób odbiło się to także na systemie oświaty i miało duży wpływ na dalsze funkcjonowanie szkół polskich na terenie Imperium. W wyniku tych zmian najważniejszym ośrodkiem naukowym ziem litewsko-ruskich stał się Cesarski Uniwersytet Wileński - przekształcony ze Szkoły Główniej Wielkiego Księstwa Litewskiego, a wszystkie placówki oświatowe w zaborze rosyjskim przeszły pod zwierzchnictwo uczelni wileńskiej, w tym częściowo również te, które wcześniej podlegały Szkole Głównej Koronnej w Krakowie. Pod opieką odnowionego uniwersytetu znalazły się więc zarówno szkoły, które przetrwały zawieruchę rozbiorów, jak i nowe, powstałe w okresie funkcjonowania Wileńskiego Okręgu Naukowego.

Od czasu objęcia władzy w cesarstwie przez Aleksandra I, na terenie Rosji osiągnięcia oświatowe KEN z powodzeniem wykorzystywali Adam Jerzy Czartoryski, Hieronim Stroynowski, Seweryn Potocki, Hugo Kołłątaj, Tadeusz Czacki i wielu innych. Z jednej strony brali oni udział w reformowaniu szkolnictwa rosyjskiego (opierając się na założeniach i ideach KEN), z drugiej starali się w jego strukturze zachować, a nawet rozwinąć szkoły polskie. Doszło nawet do tego, że w Imperium Rosyjskim właściwie „nie było niemal dziedziny życia szkolnego, kierunku, ideału, które by nie czerpały z dorobku KEN" . W tym kontekście, w zaborze rosyjskim zaczęła się również zmieniać sytuacja wielu szkól już wcześniej podległych Komisji.

7 S. Truchim, Wspótpraca polsko-rosyjska nad organizacją szkolnictwa rosyjskiego w początkach XIX w., Łódź 1960, s. 19. Por. J. Dunin-Karwicki, Szkice obyczajowe i historyczne, Warszawa 1882, s. 90-91; A.J. Mikulski, Dziatalność oświatowa Tadeusza Czackiego, Poznań 1913, s. 15; A. Osiński, O życiu i pismach Tadeusza Czackiego Taynego Radźcy Jego Imperatorskiey Mości..., Krzemieniec 1816, s. 72-75.

$8 \quad$ K. Mrozowska, Tradycje Komisji Edukacji Narodowej w szkolnictwie polskim w XIX wieku, dz. cyt., s. 403. 


\section{Nadzieje zwiqzane ze wstapieniem na tron cara Aleksandra I}

Nadzieje, jakie wiązano $\mathrm{z}$ nowym carem, były uzasadnione zarówno dążeniami reformatorskimi młodego władcy, jak i faktem, że w jego otoczeniu znalazło się wielu Polaków. Dotyczy to szczególnie księcia Adama Jerzego Czartoryskiego, który wywarł znaczący wpływ na decyzje cesarza dotyczące administracji państwowej, a w szczególności w dziedzinie oświaty. Jego troską były też starania o zachowanie polskości na terenach zagarniętych przez Rosję, a jednym ze sposobów realizacji tej idei było propagowanie nauczania w języku polskim. A.J. Czartoryski, poza zaspokajaniem osobistych ambicji i interesów, podejmował więc starania o zachowanie polskiej kultury na ziemiach zaboru rosyjskiego.

Warto podkreślić, że w Rosji idee i koncepcje Komisji Edukacji Narodowej naśladowano już za panowania Katarzyny II, bowiem w 1782 roku został opracowany, rozpatrzony i zatwierdzony plan organizacji szkół w całym imperium, w myśl którego, niejako na wzór KEN, szkoły w Rosji dzieliły się na trzy stopnie: dwuklasowe małe szkoły, trzyklasowe szkoły średnie i szkoły główne. Również ukaz w sprawie uporządkowania szkolnictwa prywatnego z 1784 roku bardzo przypominal treść Przepisów od Komisji Edukacji Narodowej pensjomistrzom i mistrzyniom danych, które zostały ogłoszone przez Komisję w 1776 roku9 . Poza tym na ziemiach, które dostały się pod panowanie rosyjskie w pierwszym rozbiorze, zachowały się jeszcze szkoły zakonne (w większości jezuickie). Katarzyna II nie uznała bowiem decyzji papieża Klemensa XIV z 1773 roku o likwidacji zakonu, tym samym zezwoliła jezuitom na prowadzenie na terenie zajętym przez Rosjan kilkunastu szkół różnego stopnia. Z kolei na obszarach włączonych do Rosji w wyniku drugiego i trzeciego rozbioru funkcjonowały jeszcze szkoły polskie zreformowane i założone przez KEN. Stosunek Katarzyny II do tych placówek był jednak zdecydowanie wrogi ${ }^{10}$.

9 S. Truchim, Wspótpraca polsko-rosyjska nad organizacja szkolnictwa rosyjskiego w poczatkach XIX w., dz. cyt., s. 16-19.

10 M.in. D. Beauvois, Wilno - polska stolica kulturalna zaboru rosyjskiego 18031832, Wrocław 2010, s. 29; R.W. Wołoszyński, Polacy w Rosji, 1801-1830, Warszawa 1984, s. 8; R. Wroczyński, Dzieje ośrwiaty polskiej 1795-1945, Warszawa 1987, s. 29. 


\section{Udział Polaków w reformowaniu szkolnicłwa rosyjskiego}

$\mathrm{Na}$ terenie Imperium Rosyjskiego rozwój nowoczesnego szkolnictwa zaczął się faktycznie od momentu, kiedy car Aleksander I reorganizując administrację państwa w 1802 roku powołał pierwsze w dziejach imperium ministerstwo ds. oświaty. Niemal równocześnie utworzono tzw. Komisję Szkolną, w której skład weszli także Polacy - ks. Adam Jerzy Czartoryski i hr. Seweryn Potocki. Należy jednak podkreślić, że głównym orędownikiem reform $\mathrm{w}$ dziedzinie oświaty był ks. Czartoryski, w owym czasie bliski współpracownik młodego cara. Warto przy tym dodać, że książę Adam Jerzy Czartoryski w sprawach oświatowych konsultował się ze swoim ojcem Adamem Kazimierzem, który oprócz tego, że był związany ze Szkołą Rycerską w Warszawie, z ramienia KEN pełnił również funkcję wizytatora szkół podległych Komisji ${ }^{11}$. Nic więc dziwnego, że ustalona wówczas organizacja szkolnictwa w Rosji oparta była na wzorach polskich.

Na początku panowania Aleksandra I projekty zmian w Imperium Rosyjskim były dyskutowane jedynie w wąskim gronie jego przyjació - Adama Jerzego Czartoryskiego, Pawła Stroganowa, Mikołaja Nowosilcowa i Wiktora Koczubeja. Tworzyli oni tzw. Nieoficjalny Komitet, zwany też Tajnym, z którym młody car ściśle współdziałał w pracach nad reformą państwa. Pierwsze posiedzenie Tajnego Komitetu, poświęcone reformie oświaty w Rosji, miało miejsce 23 grudnia 1801 roku. Na owym posiedzeniu przyjaciele Aleksandra I głosowali m.in. za utworzeniem ministerstwa ds. oświaty, bowiem spośród projektów reform w Rosji oświata publiczna zajmowała czołowe miejsce ${ }^{12}$. Nie było też sprawą przypadku, że już 10 lutego 1802 roku na posiedzeniu Tajnego Komitetu książę Czartoryski przedstawił carowi projekt organizacji najwyższych władz administracji państwowej. Według koncepcji księcia najwyższa władza administracyjna spoczywać miała w ręku ośmiu ministerstw, a na pierwsze miejsce

11 Zob. D. Beauvois, Wilno - polska stolica kulturalna zaboru rosyjskiego 1803-1832, dz. cyt., s. 30-31; J. Skowronek, Adam Jerzy Czartoryski 1770-1861, Warszawa 1994, s. 65.

12 A. Szmyt, Gimnazjum i Liceum Wotyńskie w Krzemieńcu w systemie oświaty Wileńskiego Okregu Naukowego 1805-1833, Olsztyn 2009, s. 33. Zob. też D. Beauvois, Wilno - polska stolica kulturalna zaboru rosyjskiego 1803-1832, dz. cyt., s. 30 . 
Czartoryski wysunął ministerstwo mające nadzorować system oświaty. Car oraz członkowie Nieoficjalnego Komitetu zgodzili się bez zastrzeżeń z projektem Czartoryskiego, uzupełniając go swoimi uwagami ${ }^{13}$, a rezultatem ich prac był manifest carski o utworzeniu ministerstw wydany w dniu 8 września 1802 roku. Po burzliwej dyskusji ustalono, że szkolnictwem zajmie się Ministerstwo Oświecenia Publicznego ${ }^{14}$.

Pierwszym Ministrem Oświecenia Publicznego został hrabia Piotr Wasylewicz (Bazylewicz) Zawadowski - syn kozaka z Ukrainy, który kształcił się m.in. w kolegium jezuickim w Orszy, stąd też doskonale opanował język polski i łacinę. Nic więc dziwnego, że odnosił się z sympatią do Polaków. Szczególnie uprzejmy był w stosunku do Czartoryskiego i nie utrudniał realizacji projektów księcia ${ }^{15}$. Niestety następcy Zawadowskiego okazali się mniej przychylni zarówno wobec Polaków, jak i oświeceniowych idei KEN ${ }^{16}$.

Opracowaniem projektu ustawy o ustroju szkół na terenie cesarstwa, a następnie jej realizacją miała się zająć tzw. Komisja Szkolna. Jej członkowie zostali zobowiązani do nadzorowania wszystkich szkół w Imperium Rosyjskim. W zarządzeniu ustalającym zakres pracy komisji szczególny nacisk położono na zakładanie i organizację uniwersytetów ${ }^{17}$. Inauguracyjne posiedzenie Komisji Szkolnej pod przewodnictwem ministra Zawadowskiego odbyło się 13 września 1802 roku, a już na posiedzeniu w dniu 27 września akademik Mikołaj Fus

13 A. Szmyt, Gimnazjum i Liceum Wotyńskie w Krzemieńcu w systemie ośriaty Wileńskiego Okręgu Naukowego 1805-1833, dz. cyt., s. 33-34. Por. [A.J. Czartoryski], Pamiętniki ks. Adama Czartoryskiego i korespondencja jego z cesarzem Aleksandrem I, słowo wstępne L. Gadon, przedmowa K. de Mazade, przeł. K. Scipio, T. 1, Kraków 1904, s. 173.

14 S. Truchim, Wspótpraca polsko-rosyjska nad organizacja szkolnictwa rosyjskiego w poczatkach XIX w., dz. cyt., s. 35-36.

15 W. Studnicki, Polityka Rosjan względem szkolnictwa zaboru rosyjskiego, Kraków 1906, s. 26. Por. D. Beauvois, Wilno - polska stolica kulturalna zaboru rosyjskiego 1803-1832, dz. cyt., s. 34-35; S. Truchim, Wspótpraca polsko-rosyjska nad organizacja szkolnictwa rosyjskiego w poczatkach XIX w., dz. cyt., s. 38 .

16 Na ten temat pisał z Wilna Jan Śniadecki do Tadeusza Czackiego w dniu 13 lipca 1806 roku - zob. B. Gubrynowicz, Z nieznanej korespondencji Jana Śniadeckiego do Tadeusza Czackiego (1806-1811), Wilno 1929, s. 4.

17 S. Truchim, Wspótpraca polsko-rosyjska nad organizacja szkolnictwa rosyjskiego w poczatkach $X I X$ w., dz. cyt., s. 42. 
wygłosił referat, w którym przedstawił szczegóły koncepcji organizacji szkolnictwa w Rosji. Zgodnie z jego projektem terytorium cesarstwa miało być podzielone na sześć okręgów. „W każdym okręgu winien zostać założony jeden uniwersytet. W miastach gubernialnych winny powstać gimnazja, w miastach powiatowych — szkoły drugiego rzędu, po wsiach — trzeciego rzędu"18. W tym projekcie niewątpliwie wyraźnie widać wpływy polskie, szczególnie w odniesieniu do piramidalnej struktury szkolnictwa ${ }^{19}$.

\section{Projekt organizacji szkolnictwa w Rosji ks. Adama Jerzego Czartoryskiego}

Wpływy polskie wyraźnie uwydatniły się także już trakcie ustalania zakresu działania Komisji Szkolnej. Chodzi tu przede wszystkim o koncepcję organizacji oświaty na terenie imperium, zakładającą podporządkowanie wszystkich szkół danego okręgu uniwersytetom oraz piramidalną hierarchię władz administracji szkolnej. Jednak w swym projekcie Fus ograniczył się tylko do naszkicowania zależności organizacyjnej szkół niższych od wyższych, nie zagłębiając się w szczegóły.

Z kolei na posiedzeniu Komisji Szkolnej w dniu 2 października 1802 roku został przedstawiony projekt organizacji szkolnictwa autorstwa księcia Adama Jerzego Czartoryskiego pt. O zasadach publicznego oświecenia w rosyjskim imperium. W dokumencie tym została uwzględniona organizacja czterech stopni szkół: parafialnych, powiatowych, gubernialnych i uniwersytetów. Istotą tego podziału, podobnie jak w strukturze KEN, była hierarchiczna zależność administracyjna szkół stopnia niższego od szkół stopni wyższych. Czartoryski również proponował utworzenie w Rosji sześciu uniwersytetów: w Moskwie, Petersburgu, Kazaniu, Dorpacie, Wilnie i Charkowie, które miały podlegać Komisji Szkolnej, ta zaś Ministrowi Oświecenia Publicznego ${ }^{20}$.

18 Tamże, s. 43.

19 Zob. m.in. Ustawy Kommissyi Edukacji Narodowej..., s. 67-68; K. Bartnicka, Ustawy dla Stanu Akademickiego i na szkoty w krajach Rzeczypospolitej przepisane. Polski kodeks szkolny z XVIII wieku, opublikowany w 1783 r. przez Komisje Edukacji Narodowej, dz. cyt., s. 53.

20 S. Truchim, Wspótpraca polsko-rosyjska nad organizacją szkolnictwa rosyjskiego w poczatkach XIX w., dz. cyt., s. 44. 
Podobnie jak w Rzeczypospolitej, uniwersytetom, wokół których miano utworzyć okręgi szkolne (naukowe) obejmujące również szkoły niższego szczebla, miała przypaść główna rola w strukturze nowoczesnego systemu oświaty ${ }^{21}$. Tak więc książę Czartoryski, podobnie jak M. Fus, zdecydowanie wykorzystywał tu koncepcję i ideę Komisji Edukacji Narodowej, a w przyszłym regulaminie oświecenia publicznego Rosji można nawet znaleźć skopiowane (często dosłownie) struktury polskie okresu KEN22.

Zaproponowany podział imperium na okręgi szkolne był po myśli Polaków, bowiem jeden z nich - okręg wileński - obejmował prowincje należące przed rozbiorami do Polski, także te przed 1772 rokiem, a jego granice pokrywały się niemal ściśle $\mathrm{z}$ granicami ziem zaboru rosyjskiego ${ }^{23}$. Mogło to oznaczać uznanie przez Aleksandra I jeśli nie polskości, to co najmniej odrębności i specyfiki ośmiu guberni wchodzących w skład Wileńskiego Okręgu Szkolnego. Nie bez znaczenia był również fakt, że ziemie zagarnięte przez Rosję w wyniku trzech rozbiorów Polski były jedynymi na terenie Imperium Rosyjskiego większymi skupiskami placówek oświatowych.

Komisja Szkolna na kolejnym posiedzeniu przyjęła szczegółowo opracowany projekt $\mathrm{z}$ uznaniem, zgadzając się z głównymi propozycjami księcia. W konsekwencji, przy układaniu ostatecznej wersji ustawy o organizacji szkolnictwa w Imperium Rosyjskim, komisja postanowiła wziąć pod uwagę koncepcję opracowaną przez Czartoryskiego, a wzorowaną na założeniach KEN. Te założenia stały się więc podstawą ustawy wprowadzającej reformę szkolnictwa w Rosji. Należy podkreślić, że faktycznym autorem owej koncepcji był najprawdopodobniej pierwszy rektor odnowionego Uniwersytetu

21 Ustawy Kommissyi Edukacji Narodowej..., s. 67-68, 70-71. Por. D. Beauvois, Wilno - polska stolica kulturalna zaboru rosyjskiego 1803-1832, dz. cyt., s. 368-369; S. Truchim, Wspótpraca polsko-rosyjska nad organizacja szkolnictwa rosyjskiego w poczatkach XIX w., dz. cyt., s. 44.

22 Por. z tekstem Ustaw Kommissyi Edukacji Narodowej...; Zob. też m.in. D. Beauvois, Wilno - polska stolica kulturalna zaboru rosyjskiego 1803-1832, dz. cyt., s. 368-369; S. Truchim, Wspótpraca polsko-rosyjska nad organizacja szkolnictwa rosyjskiego w początkach XIX w., dz. cyt., s. 63-90.

23 D. Beauvois, Wilno - polska stolica kulturalna zaboru rosyjskiego 1803-1832, dz. cyt., s. 369. Por. S. Truchim, Wspótpraca polsko-rosyjska nad organizacja szkolnictwa rosyjskiego w poczatkach XIX w., dz. cyt., s. 129-133. 
Wileńskiego ksiądz Hieronim Stroynowski ${ }^{24}$. Jednakże projekt organizacji szkolnictwa w Rosji, jak i inne koncepcje Stroynowskiego z zakresu oświaty, podpisywał i przedstawiał na posiedzeniach Komisji Szkolnej wyłącznie książę Czartoryski.

Nie ulega też wątpliwości, że duży wpływ na poglądy pedagogicznie księcia, a tym samym na ostateczny kształt projektu organizacji szkolnictwa w Rosji miał ojciec Adama Jerzego - ks. Adam Kazimierz Czartoryski. Synowi służył on także radą, pomocą i przestrogą w okresie pełnienia przez niego funkcji kuratora. O tym możemy się przekonać analizując m.in. bogatą korespondencję między ojcem i synem, w której wiele miejsca obaj Czartoryscy poświęcili właśnie sprawom oświaty ${ }^{25}$.

\section{Podstawy organizacji i struktura nowoczesnego szkolnictwa w Imperium Rosyjskim}

Na początku 1803 roku projekt ustawy dotyczącej oświaty w Rosji był już opracowany. Wkrótce zyskał aprobatę cara Aleksandra I i dnia 24 stycznia 1803 roku ogłoszono ukaz pod nazwą Tymczasowe przepisy oświecenia publicznego, który stał się podstawą organizacji

24 O owej współpracy świadczy zresztą późniejsza korespondencja miedzy Czartoryskim a Stroynowskim - zob. Rosyjska Biblioteka Narodowa w St. Petersburgu [dalej: RBN], fond 18, sygn. 510 - Korespondencja Stroynowskiego z Czartoryskim z lat 1803-1806, k. 1-51. O roli Stroynowskiego w tworzeniu koncepcji reformy szkolnictwa w Rosji pisał też Hugo Kołłątaj-zob. [H. Kołłątaj], X. Hugona Kottataja korespondencja listowna z Tadeuszem Czackim wizytatorem nadzwyczajnym szkót, w guberniach wotyńskiej, podolskiej i kijowskiej; przedsięwzięta w celu urzadzenia instytutów naukowych $i$ pomnożenia oświecenia publicznego w trzech rzeczonych guberniach. Z rękopisu wydał F. Kojsiewicz, T. 1, Kraków 1844, s. 225. Por. J. Bieliński, Uniwersytet Wileński (1579-1831), T. 3, Kraków 1900, s. 51; M. Baliński, Dawna Akademia Wileńska, Petersburg 1862, s. 380, 389; M. Handelsman, Czartoryski Adam Jerzy. Czartoryscy trzydzieści sześí życiorysów, Kraków 1938, s. 146.

25 Biblioteka XX Czartoryskich w Krakowie [dalej: BCz], sygn. 819 i 1046 (dawniej tzw. Ewidencja, czyli zbiory Archiwum Domowego, obecnie włączone do pozostałych zbiorów BCz). Por. D. Beauvois, Adam Jerzy Czartoryski jako kurator wileńskiego okregu naukowego, „Przegląd Historyczny”, T. 55, 1974 , z. 1, s. 65; tenże, Wilno - polska stolica kulturalna zaboru rosyjskiego 1803-1832, dz. cyt., s. 44-45. 
nowoczesnego szkolnictwa rosyjskiego ${ }^{26}$. Dokument ten, którego podstawą był projekt ks. Czartoryskiego, sankcjonował i określał status, strukturę i zasady funkcjonowania resortu oświaty w całym Imperium, w tym również na ziemiach litewsko-ruskich. Stwierdzał także, że publiczna oświata w Rosji miała odtąd stanowić odrębną jednostkę administracji państwowej, podległą Ministerstwu Oświecenia Publicznego. Jednocześnie Komisję Szkolną przekształcono w Główny Zarząd Szkól, który odtąd miał kierować administracją szkolną pod nadzorem ministra resortu oświaty ${ }^{27}$.

W dalszej kolejności, 27 czerwca 1803 roku na wniosek ministra Zawadowskiego została też powołana Komisja Podręczników, która miała za zadanie zbadanie i weryfikację podręczników wydawanych przez Komisję Szkolną, ustanowioną jeszcze przez Katarzynę II. Poza dokonaniem analizy podręczników już wydanych, komisja miała się również zająć opracowaniem brakujących, zwłaszcza do gimnazjów. Zakres jej zadań pozwala przypuszczać, że wzorowano się na Towarzystwie Ksiąg Elementarnych KEN ${ }^{28}$.

Następstwem podziału państwa na okręgi był fakt, że już 25 stycznia 1803 roku zostali mianowani przez cara kuratorzy poszczególnych okręgów oraz pozostali członkowie Głównego Zarząadu Szkół ${ }^{29}$. Kuratorzy stanowili jednocześnie tzw. Główną Dyrekcję Szkół przy

26 Tekst ustawy (ukazu) z 24.01.1803 r. [druk w j. pol. i ros.] - zob. m.in. Biblioteka Uniwersytetu Wileńskiego [dalej: BUWil], fond 2, sygn. KC 645, k. 127-137. Por. Ukaz Aleksandra I, Imperatora do Rzadzacego Senatu wzgledem urzadzenia nauk i szkót, w państwie rosyjskim, „Nowy Pamiętnik Warszawski”, R. 1803, T. 10, Warszawa 1803, s. 175-185; I. Korniłow, Sbornik Materiatow dla istorii proswieszczenija w Rossiji, T. 2, St. Petersburg 1897, s. 139-147; S. Truchim, Wspótpraca polsko-rosyjska nad organizacja szkolnictwa rosyjskiego w poczatkach XIX w., dz. cyt., s. 47-48, 129-133.

27 Szczegółowa rola Głównego Zarządu Szkół została określona w paragrafie pierwszym rozdziału pierwszego w/w ustawy - zob. m.in. BUWil, f. 2, sygn. KC 645, k. 127-128. Por. I. Korniłow, Sbornik Materiatow dla istorii proswieszczenija w Rossiji, dz. cyt., s. 139-140.

28 S. Truchim, Wspótpraca polsko-rosyjska nad organizacja szkolnictwa rosyjskiego w poczatkach XIX w., dz. cyt., s. 49.

29 Ukaz Aleksandra I, Imperatora do Rzadzqcego Senatu..., s. 186; S.W. Rożdiestwienskij, Istoriczeskij obzor diejatelnosti Ministerstwa Narodnogo Proswieszczenija, St. Petersburg 1902, s. 44. Zob. też D. Beauvois, Wilno-polska stolica kulturalna zaboru rosyjskiego 1803-1832, dz. cyt., s. 31-32; S. Truchim, Wspótpraca polsko-rosyjska nad organizacja szkolnictwa rosyjskiego w początkach XIX w., dz.cyt., s. 48. 
Ministrze Oświecenia Publicznego. Odgrywali również rolę faktycznych naczelników swoich wydziałów i byli zarazem łącznikami między okręgiem a władzami centralnymi ${ }^{30}$.

Prace Głównego Zarządu Szkół nad tworzeniem nowoczesnego systemu szkolnictwa w Rosji nie ograniczyły się wyłącznie do podjęcia czynności organizacyjnych i przebudowy administracji resortu oświaty. Ważnym zadaniem było opracowanie zasad funkcjonowania niższych szczebli szkolnictwa. Przykładowo, 5 maja 1803 roku została wydana Instrukcja dla wizytatoróww, czyli dla nadzorców wszystkich szkół niższego szczebla. Priorytetem dla Głównego Zarządu Szkół było jednak opracowanie ustawy zasadniczej dla uniwersytetów. Ostatecznie zrezygnowano z ułożenia ustawy ogólnej, a skoncentrowano się nad opracowaniem projektów ustaw (statutów) dla każdej z sześciu uczelni z osobna. Przygotowaniem projektu statutu dla Uniwersytetu Wileńskiego zajął się ks. Adam Jerzy Czartoryski, ale opracowanie tego dokumentu ponownie powierzył Hieronimowi Stroynowskiemu. Projekt, wzorowany na Ustawach Komisji Edukacji Narodowej, przedyskutowany wcześniej na posiedzeniu Głównego Zarządu Szkól, został zatwierdzony przez cara 18 maja 1803 roku pod nazwą Ustawy Uniwersytetu Wileńskiego i szkót jego wydziatu ${ }^{31}$. Wcześniej, na posiedzeniu Komisji Szkolnej w dniu 4 października 1802 roku, minister Piotr Zawadowski zwrócił się do ks. Adama Jerzego Czartoryskiego oraz hr. Seweryna Potockiego o zajęcie się sprawami organizacji Uniwersytetu Wileńskiego. Mieli oni zainteresować się rozporządzeniami KEN dotyczącymi majątku dawnej

30 M.in. M. Ambros, Zarys statystyczny szkót wydziatu wileńskiego, Wilno 1939, s. 2-3(146-147); D. Beauvois, Adam Jerzy Czartoryski jako kurator wileńskiego okregu naukowego, dz. cyt., s. 62; Tenże, Wilno-polska stolica kulturalna zaboru rosyjskiego 1803-1832, dz. cyt., s. 40-42; S. Truchim, Wspótpraca polsko-rosyjska nad organizacja szkolnictwa rosyjskiego w poczatkach XIX w., dz. cyt., s. 53-54.

31 Zob. Ustawy czyli ogólne postanowienia Imperatorskiego Uniwersytetu Wileńskiego i Szkót jego wydziatu [z 18 maja 1803 r.], „Nowy Pamiętnik Warszawski”, R. 1803, T. 11, Warszawa 1803, s. 336-363. Przedruk zob. m.in. J. Kamińska, Universitas Vilnensis 1793-1803. Od Szkoty Gtównej Wielkiego Księstwa Literwskiego do Imperatorskiego Uniwersytetu Wileńskiego, Warszawa 2012, Aneks nr 1. Por. Ustawy Kommissyi Edukacji Narodowej..., s. 67-81; K. Bartnicka, Ustawy dla Stanu Akademickiego i na szkoty w krajach Rzeczypospolitej przepisane. Polski kodeks szkolny z XVIII wieku, opublikowany w 1783 r. przez Komisje Edukacji Narodowej, dz. cyt., s. 53. 
Szkoły Głównej Wielkiego Księstwa Litewskiego i zależnych od niej szkół niższego szczebla ${ }^{32}$.

$\mathrm{Z}$ kolei w dniu 5 listopada 1804 roku została ogłoszona Ustawa o naukowych zaktadach podporzadkowanych uniwersytetom. Była ona właściwie szczegółowym rozwinięciem zasad zawartych we wcześniejszej ustawie z 24 stycznia 1803 roku, czyli w Tymczasowych przepisach oświecenia publicznego, a także niektórych postanowień zawartych w ustawach uniwersyteckich. Dokument ten faktycznie zamknął ustawodawczą część pracy nad organizacją nowoczesnego systemu szkolnictwa w Imperium Rosyjskim ${ }^{33}$.

Należy podkreślić, że Tymczasowe przepisy, podobnie jak wcześniejsze Ustawy KEN, sankcjonowały piramidalną strukturę szkolnictwa. Tym samym określały typy i stopnie szkół w cesarstwie. Zgodnie z tym dokumentem, poza uniwersytetami, $\mathrm{w}$ poszczególnych okręgach miały funkcjonować szkoły gubernialne czyli gimnazja (u nas szkoły wojewódzkie), szkoły powiatowe i parafialne. Ponieważ jednak taka organizacja administracji szkolnej istniała wcześniej tylko w Polsce, z całą pewnością można stwierdzić, że wzór do ostatecznego projektu Tymczasowych przepisów zaczerpnięty został z praktyki i wzorów polskich ${ }^{34}$. Należy przy tym podkreślić, że Komisja Edukacji Narodowej nie przewidywała wprowadzonego w Rosji stanowiska kuratora.

Kuratorzy stali na czele okręgów szkolnych (naukowych), podlegając tylko ministrowi. Bezpośrednio podlegali im rektorzy uniwersytetów, którzy pełnili podwójną funkcję: $\mathrm{z}$ jednej strony zwierzchnika uczelni, z drugiej zaś zwierzchnika wszystkich szkół okręgu35.

32 S. Truchim, Wspótpraca polsko-rosyjska nad organizacją szkolnictwa rosyjskiego w poczatkach XIX w., dz. cyt., s. 47.

33 Tamże, s. 50.

34 Zob. Ustawy Kommissyi Edukacji Narodowej..., s. 67-81. Por. Ustawy Komisji Edukacji Narodowej dla stanu akademickiego i na szkoty Rzeczypospolitej przepisane, wyd. J. Lubczyński, Lwów 1930, s. 1-4; K. Bartnicka, Wychowanie patriotyczne w szkotach Komisji Edukacji Narodowej, Warszawa 1973, s. 136-138; D. Beauvois, Wilno - polska stolica kulturalna zaboru rosyjskiego 1803-1832, dz. cyt., s. 369-370; T. Mizia, O Komisji Edukacji Narodowej, Warszawa 1972, s. 44, 106; S. Truchim, Wspótpraca polsko-rosyjska nad organizacja szkolnictwa rosyjskiego w początkach XIX w., dz. cyt., s. 43.

35 S. Truchim, Wspótpraca polsko-rosyjska nad organizacją szkolnictwa rosyjskiego w poczatkach XIX w., dz. cyt., s. 54. Por. M. Ambros, Zarys statystyczny szkót wydziatu wilenskiego, dz. cyt., s. 8(152); D. Beauvois, Wilno - polska stolica kulturalna zaboru rosyjskiego 1803-1832, dz. cyt., s. 63-64. 
W określonych rejonach (guberniach) poszczególnych okręgów, faktycznymi zastępcami kuratorów byli z kolei wizytatorzy, którzy $\mathrm{w}$ hierarchii administracji szkolnej stali pomiędzy uniwersytetem a kuratorem. $\mathrm{Na}$ kolejnym szczeblu w hierarchii administracyjnej szkolnictwa w Rosji stali dyrektorzy (kierownicy) gimnazjów i kierownicy szkół powiatowych. Stanowili oni naturalny łącznik pomiędzy nauczycielami i władzami uniwersyteckimi ${ }^{36}$. Wśród nich najważniejsi byli oczywiście dyrektorzy gimnazjów, którzy podobnie jak rektorzy również pełnili podwójne funkcje: kierownictwa nad gimnazjami oraz nadzoru nad szkołami powiatowymi i parafialnymi, a także nad placówkami prywatnymi, jak np. pensje. Szkoły parafialne, czyli podstawowe placówki edukacyjne zakładane przy poszczególnych parafiach, w miastach i na wsi, nie miały w zasadzie formalnych kierowników. $\mathrm{Na}$ tym poziomie uniwersytety oddały inicjatywę głównie Kościołowi, społeczności wiejskiej i posiadaczom ziemskim ${ }^{37}$.

Na podstawie ukazu (instrukcji) z 26 sierpnia 1811 roku w Rosji utworzono też instytucję dozorców honorowych, którzy byli łącznikami między szkołą a społeczeństwem i jednocześnie propagatorami oświaty publicznej. Dozorcy honorowi byli wybierani przez Ministra Oświecenia Publicznego spośród zamożnych i wpływowych obywateli danego regionu ${ }^{38}$.

Przedstawiony wyżej hierarchiczny układ zarządzania szkołami, wprowadzony na terenie Imperium Rosyjskiego na podstawie Tymczasowych przepisórw, także musiał wzorować się na koncepcji KEN, tym bardziej, że niektóre zalecenia dla urzędników oświatowych ściśle naśladowały postanowienia Komisji.

36 Szerzej zob. D. Beauvois, Wilno - polska stolica kulturalna zaboru rosyjskiego 1803-1832, dz. cyt., s. 400-409.

37 M. Ambros, Zarys statystyczny szkót wydziatu wileńskiego, dz. cyt., s. 15(159). Szerzej na ten temat zob. np. Ustawy dla Szkót Parafialnych w Guberniach Wotyńskiey, Kijowskiey i Podolskiey... z 31 sierpnia 1807 r., [b.m.r.w.], s.1-18; D. Beauvois, Wilno - polska stolica kulturalna zaboru rosyjskiego 1803-1832, dz. cyt., s. 691 i n.

38 Szerzej zob. M. Ambros, Zarys statystyczny szkót wydziatu wileńskiego, dz. cyt., s. 6(150); D. Beauvois, Wilno-polska stolica kulturalna zaboru rosyjskiego 1803-1832, dz. cyt., s. 428-435; J. Bieliński, Uniwersytet Wileński (15791831), T. 1, Kraków 1899, s. 225 i n. Zob. też m.in. Centralne Państwowe Archiwum Historyczne Ukrainy w Kijowie [dalej: CPAHU], fond 710, opis 1, dzieło 69, k. 196-197v. 


\section{Wileński Okręg Naukowy (Szkolny)}

Spośród sześciu okręgów utworzonych na podstawie ukazu Aleksandra I z dnia 24 stycznia 1803 roku, granice jednego z nich odpowiadały niemal dokładnie granicom ziem zagarniętych przez Rosję w kolejnych zaborach. Był to Wileński Okręg Naukowy (Szkolny), zwany też wydziałem. Terytorialnie okręg ten był nieco większy niż obszar przyłączony do Imperium Rosyjskiego w trzech zaborach i obejmował osiem guberni wówczas już zachodniej części cesarstwa: wileńską, grodzieńską, witebską, mińską, mohylewską, wołyńską, podolską i kijowską, czyli faktycznie wcześniejsze województwa bracławskie, podolskie, wołyńskie, kijowskie, brzesko-litewskie, nowogródzkie, mścisławskie, witebskie, mińskie, nowogródzkie, trockie, wileńskie i księstwo żmudzkie ${ }^{39}$. Kilka lat później, tj. 25 listopada 1810 roku do okręgu wileńskiego przyłączono obwód białostocki, uzyskany od Prus, na podstawie traktatów w Tylży z 7 i 9 lipca 1807 roku. Wreszcie od 27 lipca 1815 roku wydział wileński objął również szkołę powiatową misjonarzy w Iłłukszcie w guberni kurlandzkiej, która wcześniej należała do okręgu dorpackiego. Z kolei 12 stycznia 1812 roku odpadły z okręgu wileńskiego wszystkie istniejące jeszcze szkoły jezuickie, mimo że znajdowały się na jego terytorium. Szkoły te podporządkowano Akademii Połockiej. $Z$ okręgu wyłączono również pensje żeńskie, prowadzone przez zakony rzymsko-katolickie i bazyliańskie, które ukazem z dnia 23 października 1811 roku poddano władzy kościelnej. Ukazem z dnia 31 września 1818 roku Wileńskiemu Okręgowi Szkolnemu odebrano również gubernię kijowską, którą przyłączono do wydziału charkowskiego ${ }^{40}$. Po represjach wobec młodzieży akademickiej i szkolnej z 1824 roku pod zwierzchnictwo uniwersytetu petersburskiego dostały się prowincje białoruskie, czyli gubernie mohylewska i mińska ${ }^{41}$.

39 Od ministra powszechnego oświecenia do rady uniwersytetu Wileńskiego [z 30 stycznia 1803 r.], „Nowy Pamiętnik Warszawski” 1803, T. 10, Warszawa 1803, s. 187.

40 D. Beauvois, Wilno - polska stolica kulturalna zaboru rosyjskiego 1803-1832, dz. cyt., s. 378-379.

41 Tamże. Por. M. Ambros, Zarys statystyczny szkót wydziatu wileńskiego, dz. cyt., s. 3(147). D. Beauvois podaje, że gubernie wołyńska i podolska, podobnie jak wcześniej kijowska, przeszły pod zarząd uniwersytetu w Charkowie (31 października 1824 r.), wydaje się to jednak mało prawdopodobne, ponieważ po 
Dzięki stworzonej wcześniej na tym terenie przez KEN sieci szkół, mimo ewidentnych braków i marazmu, który nastąpił na ziemiach litewsko-ruskich po kolejnych rozbiorach, Wileński Okręg Naukowy zdecydowanie wyróżniał się na tle pozostałych okręgów w Imperium Rosyjskim. Jak wiadomo, było tam największe zagęszczenie placówek oświatowych, a w porównaniu do innych okręgów wyróżniał go polski charakter i polski język nauczania we wszystkich typach szkół, począwszy od Uniwersytetu Wileńskiego, a na szkołach parafialnych skończywszy. W spadku po KEN, szkolnictwo na obszarze zaboru rosyjskiego posiadało jeszcze liczne i dobrze przygotowane kadry nauczycielskie. $Z$ tego też względu zdystansować oświatowo ziem polskich Rosja nie była w stanie. Na terenach przyłączonych do Rosji szkoły były więc albo polskie, albo ich nie było w ogóle. Można więc śmiało powiedzieć, że w rosyjskiej strukturze szkolnictwa był to okręg wzorcowy.

$\mathrm{Na}$ terenie zaboru rosyjskiego wiele szkół pozostało po działalności KEN, była również spora liczba nauczycieli, którzy mogli pracować $\mathrm{w}$ nowych warunkach ${ }^{42}$. W porównaniu z pozostałą częścią imperium osiem guberni należących do Wileńskiego Okręgu Szkolnego miało to, czego często brak było pozostałym - długoletnią tradycję szkolnictwa, głównie zakonnego, ale również świeckiego. Nic więc dziwnego, że wpływ i siła istniejącej już wcześniejszej tradycji były tam wyraźnie dostrzegane ${ }^{43}$.

objęciu władzy kuratorskiej przez M. Nowosilcowa wszelkie pisma, sprawozdania i raporty ze szkoły krzemienieckiej nadal kierowane były do Uniwersytetu Wileńskiego, podobnie w kierunku odwrotnym kierowana była korespondencja dotycząca tejże szkoły. Dowodzi to, że gubernie wołyńska i podolska należały do Wileńskiego Okręgu Naukowego do momentu jego rozwiązania $\mathrm{w}$ dniu 1 maja $1831 \mathrm{r}$. Potwierdzają to dokumenty dotyczące okręgu, uniwersytetu i podległych mu szkół - zob. m. in. BUWil., f. 2, sygn. KC 57, KC 293, KC 306; Litewskie Państwowe Archiwum Historyczne w Wilnie [dalej: LPAH], fond 567, opis 2, dzieło 1631, 1634, 2063, 2073, 2074, 2298, 2720, 6511; tamże, f. 721, op. 1, d.. 359, 525-528, 36598, 36632; CPAHU, f. 707, op. 1, rkps 558-587a; tamże, op. 314(1818), d. 20; tamże, op. 316, d. 32; CPAHU, f. 710, op. 1, d. 69, 98-99, 292, 294, 298, 310, 488, 612-615.

42 K. Mrozowska, Tradycje Komisji Edukacji Narodowej w szkolnictwie polskim w XIX wieku, dz. cyt., s. 408.

43 Na ten temat zob. też m.in. J. Dybiec, Tradycje Komisji Edukacji Narodowej na ziemiach litewsko-ruskich w pocz. XIX wieku, w: Na przetomie wieków. Studia z dziejów KEN, „Studia Pedagogiczne”, R. 29, Wrocław 1973, s. $181-222$. 
Centrum oświaty na ziemiach litewsko-ruskich zostało oczywiście Wilno, z odnowioną Szkołą Główną Wielkiego Księstwa Litewskiego jako Uniwersytetem Cesarskim (Imperatorskim). Było to uznanie jedności ziem zaboru rosyjskiego, a jednocześnie możliwość kontynuacji idei KEN w warunkach niewoli, zaś środowisko wileńskie, tak jak wcześniej, zostało podzielone między dwa powołania: z jednej strony ośrodka naukowego i dydaktycznego, z drugiej - faktycznego centrum kierowniczego i kontrolnego dla szkolnictwa na ziemiach mu podległych, w tym przypadku zagarniętych przez Rosję w kolejnych rozbiorach. Jednakże Uniwersytet Wileński, nawet jeśli ustanawiał normy i uważał się za autonomiczny, zależny był od ministerstwa jako ogniwa biurokratycznej machiny stanowiącej część władzy państwowej zaborcy. Podobnie było zresztą w warunkach polskich, kiedy Szkoły Główne podlegały Komisji Edukacji Narodowej ${ }^{44}$.

Administracyjnie rozmieszczenie szkół Wileńskiego Okręgu Naukowego było analogiczne jak w strukturze KEN, a więc na gubernię przypadało jedno gimnazjum, na powiat - jedna szkoła powiatowa, a szkoły parafialne miały przypadać na jedną bądź dwie parafie. Pomiędzy trzema rodzajami szkół, tak jak w całej Rosji, ustalona została znana wcześniej ze struktury KEN zależność hierarchiczna. Nauczyciele i kierownicy szkół parafialnych podlegali dyrektorom szkół powiatowych, ci natomiast podporządkowani zostali dyrektorom gimnazjów, którzy z kolei byli zależni od władz Uniwersytetu Wileńskiego. Uniwersytet panował więc nad siecią szkół w całym okręgu. Również struktura wewnętrzna szkół nie różniła się od dawnych szkół polskich ${ }^{45}$.

44 Zob. D. Beauvois, Wilno - polska stolica kulturalna zaboru rosyjskiego 1803-1832, dz. cyt., s. 32-33, 386-388. Por. Ustawy Kommissyi Edukacji Narodowej... s. 70 i n.; K. Bartnicka, Ustawy dla Stanu Akademickiego i na szkoty w krajach Rzeczypospolitej przepisane. Polski kodeks szkolny z XVIII wieku, opublikowany w 1783 r. przez Komisje Edukacji Narodowej, dz. cyt., s. 41; L. Bazylow, Spoteczeństwo rosyjskie w pierwszej połowie XIX w., Wrocław 1973, s. 322, 347.

45 Zob. m.in. Ustawy Kommissyi Edukacji..., s. 67-81; Ustawy Komisji Edukacji Narodowej..., wyd. J. Lubczyński, s. 1-4; S. Truchim, Wspótpraca polsko- rosyjska nad organizacja szkolnictwa rosyjskiego w poczatkach XIX w., dz. cyt., s. 43. Por. K. Bartnicka, Wychowanie patriotyczne w szkotach Komisji Edukacji Narodowej, dz. cyt., s. 136-138; D. Beauvois, Wilno-polska stolica kulturalna zaboru rosyjskiego 1803-1832, dz. cyt., s. 386-388; T. Mizia, O Komisji Edukacji Narodowej, dz. cyt., s. 44. 


\section{Kurator ks. A.J. Czartoryski}

Jak wiadomo, pierwszym kuratorem Wileńskiego Okręgu Naukowego, a jednocześnie tym, który najwięcej przysłużył się rozwojowi szkolnictwa polskiego na ziemiach zaboru rosyjskiego był ks. A.J. Czartoryski. Jego pierwszą wielką ideą w tej dziedzinie było nawiązanie do systemu wizytacji, pozostawionego w spuściźnie przez KEN. Będąc zwierzchnikiem wszystkich szkół na terenie Wileńskiego Okręgu Naukowego, miał jednocześnie pieczę nad cenzurą, drukarniami, instytucjami naukowymi i bibliotekami ${ }^{46}$. Czartoryski za wszelką cenę chciał zachować polski charakter i polskie wpływy w szkolnictwie na ziemiach zaboru rosyjskiego. Zresztą było to zgodne $\mathrm{z}$ jego koncepcją polityczną, zakładającą odbudowę Polski opartą na Rosji, a przynajmniej utrzymanie w ramach cesarstwa daleko idącej autonomii oraz zachowanie języka i kultury polskiej.

Dużą rolę w upowszechnianiu idei KEN na ziemiach zagarniętych przez Rosję, a jednocześnie w tworzeniu tam nowych szkół i to z polskim językiem nauczania, odegrali również wizytatorzy, a także liczni przedstawiciele szlachty polskiej, która po rozbiorach znalazła się na terenie zaboru rosyjskiego $0^{47}$. Pomysł powołania grupy wizytatorów (inspektorów), mających za zadanie informowanie uniwersytetu o funkcjonowaniu podległych mu szkół niższego stopnia (jak w czasach KEN), ks. Czartoryski podsunął profesorowi Marcinowi Poczobuttowi-Odlanickiemu jeszcze przed zatwierdzeniem statutu Cesarskiego Uniwersytetu Wileńskiego. Następnie kurator zalecił władzom uniwersytetu opracowanie instrukcji inspekcyjnej, określając

$46 \mathrm{Na}$ temat mianowania ks. A.J. Czartoryskiego na stanowisko kuratora zob. m. in. LPAH, f. 567, op. 2, d. 32; tamże, f. 721, op. 1, d. 9, k. 2-6; [A.J. Czartoryski], dz. cyt., s.17; E. Danowska, Tadeusz Czacki 1765-1813. Na pograniczu epok i ziem, dz. cyt., s. 232; M. Handelsman, Adam Czartoryski, T. 1,Warszawa 1948, s. 51-58; J. Kallenbach, Kuratorya Wileńska (1803-1823), „Biblioteka Warszawska” 1904, T. 3, s. 421-422; J. Skowronek, dz. cyt., s. 67.

47 M.in. D. Beauvois, Wilno-polska stolica kulturalna zaboru rosyjskiego 1803-1832, dz. cyt., s. 409-410; E. Danowska, Tadeusz Czacki 1765-1813. Na pograniczu epok $i$ ziem, dz. cyt., s. 232; J. Kallenbach, Kuratorya Wileńska (1803-1823), dz. cyt., s. 422-423; A. Szmyt, Gimnazjum i Liceum Wotyńskie w Krzemieńcu w systemie oświaty Wileńskiego Okręgu Naukowego 1805-1833, dz. cyt., s. 73-77. 
przy tym, jakimi sprawami powinni się zająć wizytatorzy ${ }^{48}$. Wiedzę o instytucji wizytatorów książę kurator również czerpał od swego ojca ks. Adama Kazimierza Czartoryskiego ${ }^{49}$.

Instrukcja dla wizytatorów szkół była gotowa 6 kwietnia 1803 roku i po zaaprobowaniu przez kuratora i ministra, została przekazana do realizacji 5 maja 1803 roku. Wkrótce wprowadzono ją również we wszystkich pozostałych okręgach imperium. Tym samym na grunt rosyjski został „przeszczepiony” kolejny pomysł zaczerpnięty z tradycji polskiej i $\mathrm{KEN}^{50}$. Urząd wizytatora był do tej pory nieznany w rosyjskiej administracji szkolnej, inicjatywa Czartoryskiego była więc dla Rosji nowatorska. Analiza treści instrukcji również wyraźnie dowodzi jej związków z Komisją Edukacji Narodowej ${ }^{51}$.

\section{Podsumowanie}

Porównując organizację szkolną w Polsce z czasów KEN z systemem wprowadzonym w Rosji na początku XIX wieku nie ulega wątpliwości, co było podstawowym wzorcem dla rosyjskiego systemu oświaty stworzonego za panowania Aleksandra I. Już samo porównanie administracji szkolnej w Polsce, wprowadzonej przez KEN, z Tymczasowymi przepisami i Ustawq o naukowych zaktadach podporzadkowanych uniwersytetom, stanowiącymi przecież podstawę nowej organizacji szkolnictwa w Rosji, rozwiewa wszelkie wątpli-

48 Zob. Biblioteka Narodowa w Warszawie [dalej: BN], rkps III 3296 - listy A.J. Czartoryski do M. Poczobuta z 11 lutego 1803 r. i 6 marca 1803 r.

49 M. Miterzanka, Dziatalność pedagogiczna Adama ks. Czartoryskiego Generata Ziem Podolskich, Warszawa 1931, s. 171-184.

50 Zob. Sbornik Rasporiażenij po Ministerstwu Narodnogo Proswieszczenija, T. 1, 1802-1834, St. Petersburg 1866, s. 3-9, 24 i n. Por. J. Bieliński, dz. cyt., T. 3, Wilno 1900, s. 93 i n.; E. Danowska, Tadeusz Czacki 1765-1813. Na pograniczu epok i ziem, dz. cyt., s. 235-236; S. Truchim, Wspótpraca polsko-rosyjska nad organizacja szkolnictwa rosyjskiego w poczatkach XIX w., dz. cyt., s. 134-136.

51 Porównanie instrukcji z 5.05.1803 r. z podobnymi dokumentami ogłoszonymi przez Komisję Edukacji Narodowej zob. S. Truchim, Wspótpraca polsko- rosyjska nad organizacja szkolnictwa rosyjskiego w poczatkach XIX w., dz. cyt., s. 81-90. Zob. też D. Beauvois, Wilno-polska stolica kulturalna zaboru rosyjskiego 1803-1832, dz. cyt., s. 410-411, 422-423; A. Szmyt, dz. cyt., s. 74-76. Zob. też Ustawy Kommissyi Edukacji..., s. 85-89. 
wości w tej kwestii ${ }^{52}$. Zresztą mający kierować szkolnictwem Imperium Rosyjskiego, a podległy Ministerstwu Oświecenia Narodowego Główny Zarząd Szkól, był niejako odpowiednikiem Komisji Edukacji Narodowej, z tą różnicą, że na jego czele stał minister, a na czele KEN - przewodniczący. Natomiast „różnice podporządkowań tu carowi, tam sejmowi były wynikiem odrębnych ustrojów państwowych"53.

Naśladownictwo koncepcji i idei KEN widoczne było właściwie we wszystkich elementach organizacji szkolnictwa w Imperium Rosyjskim, a bezpośredni wpływ jej zasad i koncepcji najdobitniej zaznaczył się już w ukazie reformującym szkolnictwo rosyjskie. System oświaty w Rosji wyraźnie nawiązywał bowiem do struktury stworzonej w Polsce kilkadziesiąt lat wcześniej. Naśladownictwo KEN było również widoczne w działalności mającej na celu zapewnienie podręczników dla wszystkich typów szkół. Można więc przyjąć, że oparcie szkolnictwa rosyjskiego na tradycjach Komisji Edukacji Narodowej zapewniało względną ciągłość systemu oświaty na ziemiach Rzeczypospolitej zajętych przez Rosję w kolejnych rozbiorach ${ }^{54}$.

Rosyjski system oświaty, stworzony w 1803 roku, z czasem uległ modyfikacji. Kolejni ministrowie przeważnie o sprawach szkolnictwa nie mieli większego pojęcia, jednakże mimo wyraźnego dyletanctwa każdy z nich starał się coś „zepsuć”, przez co stopniowo odrzucana była w tej dziedzinie spuścizna Oświecenia i Komisji Edukacji Narodowej. Na wskroś nowoczesny - jak na tamte czasy - system „nie oparł się niszczącemu wpływowi Świętego Przymierza" 55 .

52 S. Truchim, Wspótpraca polsko-rosyjska nad organizacja szkolnictwa rosyjskiego w poczatkach XIX w., dz. cyt., s. 62-63. Szerzej zob. BUWil., f. 2, sygn. KC 645, k. $127-137$

53 S. Truchim, Wspótpraca polsko-rosyjska nad organizacja szkolnictwa rosyjskiego w poczatkach XIX w., dz. cyt., s. 63. Por. BUWil., f. 2, sygn. KC 645, k. 127-137; Ustawodawstwo szkolne za czasów Komisji Edukacji Narodowej (1773-1793). Zebrał i opatrzył wstępem krytycznym J. Lewicki, Kraków 1925, s. 1-4.

54 Szczegółowo przedstawił to S. Truchim, Wspótpraca polsko-rosyjska nad organizacja szkolnictwa rosyjskiego w poczatkach XIX w., dz. cyt., s. 63-90. Zob. też Z. Mrozowska, Tradycje Komisji Edukacji Narodowej w szkolnictwie polskim w XIX wieku, dz. cyt., s. 407-408.

55 D. Beauvois, Wilno - polska stolica kulturalna zaboru rosyjskiego 1803-1832, dz. cyt., s. 378 . 


\section{BIBLIOGRAFIA}

\section{Archiwalia}

Biblioteka XX Czartoryskich w Krakowie, sygn. 819 i 1046.

Biblioteka Narodowa w Warszawie, rkps III 3296.

Biblioteka Uniwersytetu Wileńskiego, fond (zespół) 2, sygn. KC 57, 293, 306,645 .

Centralne Państwowe Archiwum Historyczne Ukrainy w Kijowie, fond 710, opis 1, dzieło 69, 98-99, 292, 294, 298, 310, 488, 612-615; fond 707, opis 1, dzieło 558-587a; opis 314(1818), dzieło 20; opis 316, dzieło 32.

Litewskie Państwowe Archiwum Historyczne w Wilnie, fond 567, opis 2, dzieło 32, 1631, 1634, 2063, 2073, 2074, 2298, 2720, 6511; fond 721, opis 1 , dzieło 9, 359, 525-528, 36598, 36632;

Rosyjska Biblioteka Narodowa w St. Petersburgu, fond 18, sygn. 510.

\section{2. Źródła drukowane}

[Czartoryski A.J.], Pamiętniki ks. Adama Czartoryskiego i korespondencja jego z cesarzem Aleksandrem I, słowo wstępne L. Gadon, przedmowa K. de Mazade, przeł. K. Scipio, T. 1, Spółka Wydawnicza Polska, Kraków 1904.

Gubrynowicz B., Z nieznanej korespondencji Jana Śniadeckiego do Tadeusza Czackiego (1806-1811), Uniwersytet Stefana Batorego, Wilno 1929.

[H. Kołłątaj], X. Hugona Kottataja korespondencja listowna z Tadeuszem Czackim wizytatorem nadzwyczajnym szkót, w guberniach wotyńskiej, podolskiej $i$ kijowskiej; przedsięwzięta w celu urządzenia instytutów naukowych i pomnożenia oświecenia publicznego w trzech rzeczonych guberniach. $\mathrm{Z}$ rękopismu wydał F. Kojsiewicz, T. 1, [s.n.], Kraków 1844.

Korniłow I., Sbornik Materiatow dla istorii proswieszczenija w Rossiji, T. 2, [s.n.], St. Petersburg 1897.

Osiński A., O życiu i pismach Tadeusza Czackiego Taynego Radźcy Jego Imperatorskiey Mości..., [s.n.], Krzemieniec 1816.

Rożdiestwienskij S. W., Istoriczeskij obzor dejatelnosti Ministerstwa Narodnogo Proswieszczenija, [s.n.], St. Petersburg 1902.

Sbornik Rasporiażenij po Ministerstwu Narodnogo Proswieszczenija, T. 1, 1802-1834, [s.n.], St. Petersburg 1866.

Ukaz Aleksandra I, Imperatora do Rzq̨dzacego Senatu względem urzqdzenia nauk i szkót, w państwie rosyjskim, „Nowy Pamiętnik Warszawski”, R. 1803, T. 10, Warszawa 1803, s. 175-185.

Ustawodawstwo szkolne za czasów Komisji Edukacji Narodowej: rozporzqdzenia, ustawy pedagogiczne i organizacyjne (1773-1793). Zebrał i zaopatrzył 
wstępem krytycznym oraz przypisami Józef Lewicki, Ministerstwo Wyznań i Oświecenia Publicznego. Komisja do badań dziejów wychowania i szkolnictwa w Polsce, M. Arct, Kraków 1925.

Ustawy czyli ogólne postanowienia Imperatorskiego Uniwersytetu Wileńskiego i Szkót jego wydziatu [z 18 maja 1803 r.], „Nowy Pamiętnik Warszawski”, R. 1803, T. 11, Warszawa 1803, s. 336-363.

Ustawy dla Szkót Parafialnych w Guberniach Wotyńskiey, Kijowskiey i Podolskiey... z 31 sierpnia 1807 r., [s.n.], [b.m.r.w.].

Ustawy Komisji Edukacji Narodowej dla stanu akademickiego i na szkoty Rzeczypospolitej przepisane, wyd. J. Lubczyński, Księg. Naukowa, Lwów 1930.

Ustawy Kommissyi Edukacji Narodowej dla Stanu Akademickiego i na szkoty w krajach Rzeczypospolitej przepisane. Wydane z oryginału ze zbiorów Biblioteki Uniwersyteckiej w Warszawie. Pierwsze pełne wydanie z tabelami i wzorami od 1783 roku. red. naukowa K. Bartnicka, Wyd. MEN, Warszawa 2015.

\section{Literatura}

Ambros M., Zarys statystyczny szkót wydziatu wileńskiego, [s.n.], Wilno 1939. Baliński M., Dawna Akademia Wileńska, [s.n.], Petersburg 1862.

Bartnicka K., Ustawy dla Stanu Akademickiego i na szkoty w krajach Rzeczypospolitej przepisane. Polski kodeks szkolny z XVIII wieku, opublikowany w 1783 r. przez Komisje Edukacji Narodowej. (Wprowadzenie do nowego wydania), w: Ustawy Kommissyi Edukacji Narodowej dla Stanu Akademickiego i na szkoty w krajach Rzeczypospolitej przepisane. Wydane z oryginału ze zbiorów Biblioteki Uniwersyteckiej w Warszawie. Pierwsze pełne wydanie z tabelami i wzorami od 1783 roku. red. naukowa K. Bartnicka, Wyd. MEN, Warszawa 2015, s. 9-53.

Bartnicka K., Wychowanie patriotyczne w szkotach Komisji Edukacji Narodowej, PZWS, Warszawa 1973.

Bazylow L., Społeczeństwo rosyjskie w pierwszej połowie XIX w., Ossolineum, Wrocław 1973.

Beauvois D., Adam Jerzy Czartoryski jako kurator wileńskiego okręu naukowego, „Przegląd Historyczny” 1974, T. 55, z. 1, s. 61-85.

Beauvois D., Wilno. Polska stolica kulturalna zaboru rosyjskiego 1803-1832, Wyd. UWr., Wrocław 2010.

Bieliński J., Uniwersytet Wileński (1579-1831), T. 1-3, Kraków 1899-1900.

Danowska E., Tadeusz Czacki 1765-1813. Na pograniczu epok i ziem, Wyd. PAU PAN, Kraków 2006.

Dunin-Karwicki J., Szkice obyczajowe i historyczne, Geberthner i Wolff, Warszawa 1882.

Dybiec J., Tradycje Komisji Edukacji Narodowej na ziemiach litewsko-ruskich w pocz. XIX wieku, w: Na przetomie wieków. Studia z dziejów KEN, „Studia Pedagogiczne”, R. 29, Wrocław 1973, s. 181-222. 
Handelsman M., Adam Czartoryski, T. 1, TNW, Warszawa 1948.

Kallenbach J., Kuratorya Wilenska (1803-1823), „Biblioteka Warszawska” 1904, T. 3, s. 421-448.

Kamińska J., Universitas Vilnensis 1793-1803. Od Szkoty Gtównej Wielkiego Księstwa Litewskiego do Imperatorskiego Uniwersytetu Wileńskiego, Wyd. UW, Warszawa 2012.

Mikulski A. J., Dziatalność oświatowa Tadeusza Czackiego, „Praca”, Poznań 1913.

Miterzanka M., Dziatalnośc pedagogiczna Adama ks. Czartoryskiego Generata Ziem Podolskich, NTP, Warszawa 1931.

Mizia T., O Komisji Edukacji Narodowej, PWN, Warszawa 1972.

Mrozowska K., Tradycje Komisji Edukacji Narodowej w szkolnictwie polskim w XIX wieku, „Przegląd Historyczno-Oświatowy” 1971, s. 404-422.

Skowronek J., Adam Jerzy Czartoryski 1770-1861, WP, Warszawa 1994.

Studnicki W., Polityka Rosyi względem szkolnictwa zaboru rosyjskiego, G. Gebethner, Kraków 1906.

Szmyt A., Gimnazjum i Liceum Wotyńskie w Krzemieńcu w systemie oświaty Wileńskiego Okregu Naukowego 1805-1833, Wyd. UWM, Olsztyn 2009.

Truchim S., Wspótpraca polsko-rosyjska nad organizacją szkolnictwa rosyjskiego w początkach XIX w., Ossolineum, Łódź-Wrocław 1960.

Wołoszyński R. W., Polacy w Rosji, 1801-1830, KiW, Warszawa 1984.

Wroczyński R., Dzieje oświaty polskiej do roku 1795, PWN, Warszawa 1987.

Wroczyński R., Dzieje oświaty polskiej 1795-1945, PWN, Warszawa 1987.

\section{ADRES DO KORESPONDENCJI}

Dr hab. Andrzej Szmyt, prof. UWM

Uniwersytet Warmińsko-Mazurski w Olsztynie,

Wydział Humanistyczny,

Instytut Historii i Stosunków Międzynarodowych

Zakład Historii XIX wieku

andrzej.szmyt@uwm.edu.pl 